Agro-Science Journal of Tropical Agriculture, Food, Environment and Extension Volume 8 Number 1 January 2009 pp. 45-50

ISSN1119-7455

\title{
INFLUENCE OF NUTRIENT SOURCE ON THE ELEMANTAL COMPOSITION OF IRRIGATED GARLIC
}

\author{
${ }^{1}$ Babatunde, F.E., ${ }^{2}$ Mofoke, A.L.E., ${ }^{1}$ Udom, G.N., and ${ }^{1}$ Mohammed, G.U \\ ${ }^{1}$ : Crop Production Programme, School of Agriculture and Agricultural Technology. P.M.B. \\ 0248. Abubakar Tafawa Balewa .University, Bauchi, Nigeria \\ 2 : Agric. Engineering Programme, School of Engineering. Abubakar Tafawa Balewa. \\ University, Bauchi, Nigeria
}

\begin{abstract}
The effect of five nutrient (fertilizer) sources on garlic (Allium sativum L.) grown under irrigation in Bauchi state was in vestigated. Irrigation was scheduled at $25 \%$ management allowable deficit, giving an irrigation interval of 4 days and gross application depth of $56 \mathrm{~mm}$ of water per application. The nutrient sources were NPK fertilizer (15:15:15), wood ash, poultry manure, and fermented cow dung slurry, while the control was zero fertilization. The composition of crop samples grown under application of the various fertilizers was assessed in the laboratory following recommended analytical procedures. Pungency level was taken as a measure of the bulb sulphur content. Results of the study indicate that NPK has the effect of significantly increasing $(p \leq 0.01)$ the bulb moisture content and crude protein level of irrigated garlic, while causing significant reduction $(p \leq 0.01)$ in the pungency of the crop relative to the control. The organic fertilizers (wood ash, poultry manure, and fermented slurry) yielded crops having relatively higher pungency with wood ash giving the highest pungency strength. The mineral contents of the crops grown with organic fertilization were equally higher than those from the control and those grown with NPK. Furthermore, the crops produced with organic fertilizers had relatively lower moisture content. Results of this study demonstrate that organic fertilizers would give better quality garlic with higher pungency than the widely used NPK fertilizer and no fertilizer application.
\end{abstract}

Key words: Garlic, Irrigation, Pungency, Fertilizer, Wood ash

\section{INTRODUCTION}

Garlic (Allium sativum L.) is a universally popular crop with varied functions to humankind. Garlic produces unique flavours savored by almost all of the world's culture (Havey, 1999). The bulb is characterized by antiseptic, diuretic, expectorating, anti-scurvy and antirheumatic properties (FAO, 2006). The multiple uses of garlic today, translates into increasing demand for the crop for domestic consumption and as production input in pharmaceutical and cosmetic industries as well.

Garlic is a cold weather perennial crop with high nutrient and water requirement (Anon, 2006). The crop is grown both under rainfed and under irrigation. Garlic is approximately $40 \%$ dry weight with the major complex carbohydrate being fructan. Its characteristic flavour results from the formation of organosulfur compounds when the precursor S-alk (en)yl cysteine sulphoxide is converted by allinase to thiosulfinate (Jones et al., (2004).
The relative pungency of the Alliums results from both genetic and environmental components (Ketter and Randle, 1998., Havey, 1999). Today, efforts to obtain higher yields of garlic have resulted in the application of various types of fertilizers. The different types of fertilizers have dissimilar concentrations of plant nutrients and therefore affect the soil environment differently. This would ultimately bear varying consequences on the pungency of garlic and other Alliums. Garlic is important because of the culinary value of its flavour and rich reserve of essential compounds like Diallyl disulfide, flavonoids and selenium amongst others (Ketter and Randle, 1998). As mankind strives to obtain higher yields of garlic through heavy application of fertilizers, such procedures must equally preserve the quality of the crop. A recent study by Cantwell et al., (2006) in California USA showed inconclusive results on the influence of different fertilizer treatment on the pungency of garlic. In their work, the pungency of garlic was 
Influence of Nutrient Source on the Elemantal Composition of Irrigated Garlic

or laboratory determination of the its.

level of allin enzyme in the crop. Results indicated a

reduction in quantity of pyruvate with increase in $\mathrm{N}$ fertilizer, whereas, the thiosulfinate level increased at higher doses of $\mathrm{N}$-fertilization. However, when subjected to $\mathrm{P}$ and $\mathrm{K}$ fertilizer treatments, both pyruvate and thiosulfinate levels increased with increasing quantity of $\mathrm{P}$ at constant $\mathrm{K}$. The trend in allin concentration was even more uncertain (Cantwell et al., 2006). This research therefore, further investigated the influence of different types of fertilizer on the pungency of garlic, particularly when grown under semi-arid tropical climate. The results serve as guide in fertilizer selection for high value garlic production.

\section{MATERIALS AND METHODS Field Experiment}

Garlic was field grown under basin irrigation at the irrigation research plot of Abubakar Tafawa Balewa University, Bauchi, Nigeria. Bauchi is in the Northern Guinea Savannah ecological zone of Nigeria, and lies within latitude $10^{\circ} 17^{1} \mathrm{~N}$ and longitude $09^{\circ} 49^{1} \mathrm{E}$ on a mean altitude of $609.3 \mathrm{~m}$ above sea level. The crops were cultivated during the 2003 / 2004 and 2004 / 2005 irrigation seasons stretching from October to March of each season.

Irrigation was scheduled at $25 \%$ Management Allowable Deficit (Cantwell et al. 2006) giving an irrigation interval of 4 days and a gross application depth of $56 \mathrm{~mm}$ of water. The application time was computed (Hart et al., 1980) to be 105 seconds, from Eq 1:

$$
T a=\frac{F n L}{600 Q u E}
$$

where:

$\mathrm{Ta}=$ application time (minutes)

$\mathrm{Fn}=$ net water requirement $(\mathrm{mm})$

$\mathrm{Q}=$ unit inflow rate, $\mathrm{m}^{2} / \mathrm{s}$

The crops were grown on basins of dimensions $3 \mathrm{~m}$ $\mathrm{x} 3 \mathrm{~m}$, hence $\mathrm{L}$ was taken as $3 \mathrm{~m}$. A small petrol engine centrifugal pump with discharge of $41 / \mathrm{s}$ was used for delivering water to the field. This gave a unit inflow rate of $1.66667 \times 10^{-3} \mathrm{~m}^{3} / \mathrm{s}$.

The experimental treatment constituted five types of fertilizers commonly used for garlic production in Africa. The treatments consisted of wood ash (16.5t/ha), poultry manure $(7.0 \mathrm{t} / \mathrm{ha})$, NPK $15: 15: 15(0.3 \mathrm{t} / \mathrm{ha})$, fermented slurry (7.0t/ha) and control (no fertilizer). These treatments were arranged in a randomized complete block design with four replications. All other production practices were the same for all the treatments. The crops were harvested when the lower third of the leaves turned brown (Anon. 2006), and cured for two weeks before

\section{Preparation of the Garlic samples}

Laboratory analyses were conducted on four randomly selected samples taken from each treatment and replicate. The selected bulbs were first peeled to remove the outer scales and then reduced to their respective cloves. The cloves from each category were coarsely chopped with a sharp knife and shuffled in separate petri dishes. Samples were taken from each lot for pungency and constituent determination

\section{Theory of Pungency}

The principal compounds of intact garlic, which serve as precursors of the characteristic flavour of garlic, are the alkyl and alkenylcysteine sulphoxides (Anon. 2006). The major substrate for the pungency reaction of garlic is (+)-S-allyl-LCysteine Sulphoxide (allin) (Anon. 2006). When the walls of garlic cloves are broken, the vacuolar enzymes allinase rapidly lyses the cytosolic alk(en)yl cysteine sulphoxides to form sulfenic acids. These immediately condense to form the alkyl alkanethiosulphinates, which is the principal flavour compound of garlic (Anon. 2006). Pyruvic acid and ammonia are equally produced as by-products of the reaction. The elements and compounds associated with this chemical reaction constitute the framework for pungency determination of the Alliums. Four pungency markers of the Alliums are:

i. Enzymatically developed pyruvate (EPY), a by-product of the allinase enzyme activity.

ii. Thiosulfinate concentration, the principal product produced by allinase activity

iii. concentration of allin, the substance for allinase activity

iv. The quantity of bulb or total sulphur. (Watson, 2005; Cantwell et al., 2006)

Sulphur is a constituent of thiosulfinate, one of the major pungency compounds of the Alliums. Use of bulb sulphur as a measure of pungency has been used over the years (Resemann and Carle, 2003; Babatunde et al., 2003; Jones et al., 2004; Watson, 2005) because it has direct bearing with the pungency compound (thiosulfinate). Pungency was therefore assessed in this study using total or bulb sulphur content. The sulphur content was determined through dry ashing following the recommended procedure (A.O.A. C., 1984).

\section{Determination of Composition and Sulphur of the Experimental Crop.}

The composition of the garlic bulbs was determined based on the relative abundance of major plant constituents viz: Moisture content (MC), Crude Protein (CP), Calcium $\left(\mathrm{Ca}^{2+}\right)$, Iron $\left(\mathrm{Fe}^{2+}\right)$, Copper $\mathrm{Cu}^{2+}$ ) and Sulphur (S). Moisture content was 
Babatunde, F.E., Mofoke, A.L.E., Udom, G.N., and Mohammed, G.U

determined using the gravimetric method while $\mathrm{CP}, \mathrm{Ca}^{2+}, \mathrm{Fe}^{2+}$, and $\mathrm{Cu}^{2+}$ were determined still through dry ashing according to recommended procedures of the A.O.A. C., (1984). Bulb sulphur was determined

from wet digested sample on CE 1020, UV Spectrophotometer Instrument (CECIL ) Instrument, Cambridge, England

\section{Data analysis}

Analysis of variance and correlation were done using the MINITAB (Version 11) computer software for the major tissue constituents of the bulb. Direct and combined contributions of some constituent to the other were obtained using a computer simulated pathway analysis newly developed by Agada and Babatunde (2007)

\section{RESULTS AND DISCUSSION}

Table 1 shows the physico-chemical properties of the experimental soil. The crops fertilized with NPK had the highest protein level averaging $82.3 \mathrm{~g} / \mathrm{kg}$, while the control crops, grown without fertilizer had an average protein content of $52.9 \mathrm{~g} / \mathrm{kg}$ (Table 2). NPK gave the highest crude protein level because it has a relatively high concentration of Nitrogen which is a major constituent of amino acids, the basic constituent of proteins (Wong et al. 2001).The recorded range of protein content of 52.9-82.3 g/ $\mathrm{kg}$ compared well with the average value of $66.7 \mathrm{~g} / \mathrm{kg}$ earlier reported by Anderson (2006).

The bulb sulphur content, which is taken as a direct measure of the degree of pungency of the crop (Jones et al., 2004; Watson, 2005), equally varied significantly $(\mathrm{p} \leq 0.01)$ among the samples, from as low as $4.0 \mathrm{~g} / \mathrm{kg}$ with NPK to $15.2 \mathrm{~g} / \mathrm{kg}$ with wood ash. On this basis, wood ash is an appropriate nutrient source for growing high pungency garlic. If however, the pungency were to be moderated to a low level, then NPK or fermented slurry would be more appropriate. Anderson (2006) had recorded sulphur content of $0.5 \mathrm{~g} / \mathrm{kg}$ to $3.7 \mathrm{~g} / \mathrm{kg}$ for garlic grown in Europe. In a related research, Resemann and Carle (2003) documented bulb sulphur content of onion (Allium cepa L.) in the range of $4.55-6.77 \mathrm{~g} / \mathrm{kg}$

Table 1: Physico-chemical properties of the Experimental Plot

\begin{tabular}{lll}
\hline Property & $2003 / 2004$ & $2004 / 2005$ \\
\hline Particle size distribution (\%) & & 62.12 \\
Sand & 63.50 & 23.42 \\
Silt & 22.50 & 14.46 \\
Clay & 14.00 & Sandy Loam \\
Soil Texture & Sandy Loam & 5.32 \\
$\mathrm{pH}($ water $1: 1)$ & 5.13 & 4.78 \\
$\mathrm{pH}\left(0.01 \mathrm{mCacl}{ }_{2}\right)$ & 4.63 & 6.53 \\
Organic Carbon $(\mathrm{g} / \mathrm{kg})$ & 6.20 & 0.89 \\
Total Nitrogen $(\mathrm{g} / \mathrm{kg})$ & 0.86 & 8.02 \\
Available phosphorus $(\mathrm{mg} / \mathrm{kg})$ & 7.84 & 2.93 \\
Exchangeable Bases $(\mathrm{mol}(+) / \mathrm{kg})$ & & 0.51 \\
$\mathrm{Ca}$ & 2.88 & 0.28 \\
$\mathrm{Mg}$ & 0.53 & 0.13 \\
$\mathrm{~K}$ & 0.26 & 6.20 \\
$\mathrm{Na}$ & 0.12 & 7.34 \\
$\mathrm{Cation}$ Exchange Capacity & 6.26 & 62.09 \\
$\mathrm{C}: \mathrm{N}$ & 7.21 & 2.87 \\
$\mathrm{Base}$ Saturation $(\%)$ & 60.54 & 1.04 \\
$\mathrm{Micronutrients}(\mathrm{mg} / \mathrm{kg})$ & & 0.72 \\
\hline $\mathrm{Fe}$ & 2.58 & \\
$\mathrm{Zn}$ & 0.98 & \\
$\mathrm{Cu}$ & 0.67 & \\
\hline
\end{tabular}

Table 2: Effect of Nutrient Sources on the Elemental Composition of Irrigated Garlic

\begin{tabular}{lccccccc}
\hline \multicolumn{1}{c}{ Nutrient Source } & $\begin{array}{c}\text { Crude } \\
\text { Protein } \\
(\mathrm{g} / \mathrm{kg})\end{array}$ & $\begin{array}{c}\text { Ash Content } \\
(\mathrm{g} / \mathrm{kg})\end{array}$ & $\begin{array}{c}\text { Moisture Content } \\
(\%)\end{array}$ & $\begin{array}{c}\mathrm{Ca} \\
(\mathrm{g} / \mathrm{kg})\end{array}$ & $\begin{array}{c}\mathrm{Fe} \\
(\mathrm{g} / \mathrm{kg})\end{array}$ & $\begin{array}{c}\mathrm{Cu} \\
(\mathrm{g} / \mathrm{kg})\end{array}$ & $\begin{array}{c}\mathrm{S} \\
(\mathrm{g} / \mathrm{kg})\end{array}$ \\
\hline NPK & $82.3 \pm 0.03$ & $5.1 \pm 0.02$ & $74.4 \pm 0.02$ & $1.2 \pm 0.03$ & $1.4 \pm 0.02$ & $0.7 \pm 0.06$ & $4.0 \pm 0.20$ \\
Wood Ash & $63.5 \pm 0.02$ & $22.9 \pm 0.03$ & $56.1 \pm 0.02$ & $5.3 \pm 0.04$ & $2.6 \pm 0.06$ & $1.9 \pm 0.02$ & $15.2 \pm 0.03$ \\
Poultry Manure & $69.0 \pm 0.04$ & $15.1 \pm 0.02$ & $50.4 \pm 0.01$ & $2.7 \pm 0.02$ & $1.8 \pm 0.06$ & $1.1 \pm 0.06$ & $8.4 \pm 0.05$ \\
Fermented Slurry & $60.1 \pm 0.01$ & $10.6 \pm 0.05$ & $51.9 \pm 0.03$ & $2.0 \pm 0.05$ & $1.6 \pm 0.08$ & $0.9 \pm 0.09$ & $7.6 \pm 0.03$ \\
Control & $52.9 \pm 0.06$ & $5.9 \pm 0.12$ & $60.7 \pm 0.04$ & $1.6 \pm 0.21$ & $1.2 \pm 0.02$ & $0.9 \pm 0.10$ & $6.8 \pm 0.06$ \\
LSD 0.05 & 1.3 & 4.2 & 5.9 & 7.0 & 3.5 & 0.7 & 1.3 \\
\hline
\end{tabular}


still for common European varieties. Results of this study therefore show that the sulphur content, and hence pungency of garlic grown under tropical environment could be up to 4 times higher than those grown under temperate weather conditions. Table 2 further shows that NPK had the effect of increasing the bulb moisture content. This tendency apparently stemmed from the high Nitrogen concentration of the fertilizer.

The negative signs in Table 3 , however, show that moisture content has a negative relationship with Ash content and Bulb sulphur content. Using a fertilizer like NPK that leads to high moisture accumulation in garlic would result in the reduction in both the ash and sulphur contents of the bulbs. This can also be attributed to the fact that, the $\mathrm{K}$ component of NPK has the ability to bind to elements with non-bonding pairs of electrons such as sulphur (Personal communication with a Professor of Analytical Chemistry). Table 3 again revealed that to attain high protein levels in irrigated garlic, the moisture content would equally increase. However, the $\mathrm{Cu}, \mathrm{Ca}, \mathrm{Fe}$, and ash levels would drop. $\mathrm{Fe}$ is important in crop physiology because it is used in the biochemical reactions that form chlorophyll, and is a part of one of the enzymes that is responsible for the reduction of Nitrate-N to ammoniacal-N (Hochmuth et al., 2006). Calcium, on the other hand is a component of Calcium pectate, a constituent of cell wall (Hochmuth et al., 2006). High moisture content has adverse effects on storability of agricultural crops. Babatunde et a.l (2004) also reported high post harvest loss from onion bulb grown with NPK fertilizer. Thus apart from the high crude protein level offered by NPK, the fertilizer would generally not be a very good nutrient source for garlic cultivation. Table 3 further showed that usage of organic nutrient sources that increased the sulphur content of garlic, equally increased $\mathrm{Cu}, \mathrm{Ca}, \mathrm{Fe}$, and ash contents. This further reduce the bulb moisture content, which is desirable in preserving garlic over long terms. High sulphur content is particularly cherished in garlic because it provides a base for formation of alkyl alkenethiosulphinates $\left(\mathrm{R}_{1}-\mathrm{SS}(\mathrm{O})\right.$ $\mathrm{R}_{2}$ ), sulfenic acid (R-SOH) and allicin, which are the major pungency compounds of garlic (Watson, 2005; Anderson, 2006; Cantwell et al., 2006). Allicin is a natural antibiotic (about one-fiftieth as powerful as penicillin and one-tenth as powerful as tetracycline) that could kill many kinds of bacteria (Anderson, 2006). Sulphur is also the base constituent of the fatsoluble Diallyl disulfide and Diallyl trisulfide both of which have been shown to have anti-cancer and antitumor activities (Anderson, 2006). Sulphur, rather than Nitrogen is responsible for the flavour and medicinal attributes of garlic. Nevertheless, Jones et al. (2006) had reported that sulphur metabolism is intimately related to Nitrogen metabolism through a production of the amino acid cysteine. Yet, same researchers further observed that Nitrogen does not apparently affect the level of inorganic sulphur in garlic bulbs. Wood Ash and poultry manure enable attainment of increased sulphur and Nitrogen contents in garlic. These fertilizers are therefore recommended for production of garlic having good flavor and medicinal values.

Table 4 showed that Ash and crude protein contents strongly contributed to the sulphur level of irrigated garlic. The implication is that slight variations in these two constituents would easily alter the sulphur level of garlic. Since it has been demonstrated that Crude protein level has an inverse relationship with sulphur content (Table 3), Table 4 further illustrated that increasing the crude protein level especially by increasing NPK level, would cause an associated reduction of the Sculpture content and hence pungency of garlic. This observation can serve as an alternative means of reducing pungency, as may be desired by some who prefer low pungent garlic. Apart from this, cultural practices like application of wood ash and poultry manure for garlic production is encouraged because they produce high quality garlic vis-à-vis its use as spice and as a medicinal plant.

Table 3: Pearson's Correlation Coefficients among the Elemental Composition of Irrigated Garlic.

\begin{tabular}{lcccccc}
\hline & $\mathrm{Cu}$ & $\mathrm{Ca}$ & $\mathrm{Fe}$ & Moisture Content & $\begin{array}{c}\text { Ash } \\
\text { Content }\end{array}$ & $\begin{array}{c}\text { Crude } \\
\text { Protien }\end{array}$ \\
\hline $\mathrm{Ca}$ & 0.874 & & & & & \\
$\mathrm{Fe}$ & 0.825 & 0.971 & & & & \\
Moisture & -0.344 & -0.417 & -0.416 & & & \\
Content & 0.780 & 0.950 & 0.942 & -0.550 & -0.093 & \\
Ash Content & -0.206 & -0.171 & -0.057 & 0.530 & 0.919 & -0.310 \\
Crude Protien & 0.886 & 0.970 & 0.915 & -0.515 & & \\
$\mathrm{~S}$ & & & & & & \\
\hline
\end{tabular}


Babatunde, F.E., Mofoke, A.L.E., Udom, G.N., and Mohammed, G.U

Table 4: Contribution of Major Tissue Constituents to the Sulphur (Pungency) Level of

\begin{tabular}{lc}
\hline \multicolumn{1}{c}{ Irrigated Garlic.ype of } & Level of Contribution $(\%)$ \\
Contribution & \\
\hline$\underline{\text { a) Direct Contribution }}$ Moisture Content & 4.52 \\
Ash Content & 84.10 \\
Crude Protein & 5.87 \\
Total & 94.49 \\
b) Combined Contribution & \\
Moisture and Ash content & -8.26 \\
Moisture Content and Crude Protein & -4.14 \\
Ash Content and Crude Protein & 11.13 \\
Total & 1.27 \\
Residual & 1.24 \\
Grand Total & 100 \\
\hline
\end{tabular}

\section{CONCLUSION}

This research has shown that the different nutrient sources commonly used for irrigated garlic production within Nigeria, significantly affect the composition and pungency of the crop. NPK produces garlic with high moisture content and crude protein level, but the mineral composition of the bulbs would be low. High moisture content militates against prolonged storage of the crops, while the low mineral composition reduces the medicinal value of the garlic bulbs. Organic fertilizers like wood ash, poultry manure, and fermented slurry produce garlic having low moisture content, high pungency and higher mineral composition. NPK was not found to be a very suitable fertilizer for use in garlic production. Rather, organic fertilizers, particularly wood ash was recommended for production of good quality garlic.

\section{REFERENCES}

Agada, P.O. and Babatunde, F. E. (2006). Computer simulated path analysis of the direct, combined and indirect contributions of growth parameters to crop yield. PeCOP Journal of Science, Engineering \& Technology. 2 (1\&2): 50-61

Anderson, B. (2006). Gourmet Garilc Gardens: A primer on the Chemistry of Garlic. Available www.gourmetgarlicgardens.con/-16k. Accessed: February $18^{\text {th }}, 2006$

Anon. (1989). Fertilizer Use and Management Practices for Crops in Nigeria. Series 2. (Enwezor W.O. Udo, E. J. N. J. Usoroh; K. Ayotade; J. A. Adepetu; V. O. Chude: and C. I. Udegbe, Eds). Produced by the Fertilizer Procurement and Distribution Division of the Federal Ministry of Agriculture, Water Resources and Rural Development, Lagos.
Anon (2006). The Chemistry of Garlic: The Determination of The Pyruvic Acid Content of Garlic Tissue Homogenates. Available at www.garilcworld.co.uk. Accessed: $14^{\text {th }}$ February, 2006.

Association of Official Analytical Chemist (AOAC) (1984). Official Methods of Analysis. $13^{\text {th }}$ Edition. Washington, D.C. $123 \mathrm{pp}$

Babatunde, F. E., Ekanem, E. O. Sabo, M. U., Mohammed, G.U. and Yakubu, M. D. (2003). Influence of nutrient sources on the productivity and pungency of onions (Allium cepa). Agriculture, Business and Technology Joutnal, 1(1): 55-61

Babatunde, F. E. Oseni, T. O. and Auwalu, B.M. (2004). Effect of nutritional sources, mode of storage and post harvest losses on yield and economic returns in onions (Allium cepa). Journal of Horticultural Society of Nigeria. 9: 17-21

Cantwell, M., R. Voss, B. Hanson, D. May and B. Rice. (2006). Water and Fertilizer management for Garlic: Productivity, Nutrient and Water Use Efficiency, and Post harvest Quality. Report of a FREP Contact No. 97-0207.

FAO (2006).Vegetables. In: Technical Manual on Small-scale Processing of Fruits and Vegetables. FAO Corporate Document Repository. Available at: http://www.fao.org/docrep/x0209e/x02 09e00.htm Accessed: $18^{\text {th }}$ March, 2006

Hart W. E., H. G. Collins, G. Woodward and A. S. Humphreys. (1980). Design and Operation of Gravity or Surface Systems. In: "Design and Operation of farm Irrigation Systems". (Jensen M. E. ed) ASAE Monograph 3 pp. 501-566. 
Influence of Nutrient Source on the Elemantal Composition of Irrigated Garlic

Havey, M. J. (1999) Advances in New Aliums. In: Perspectives on New Crops and Uses. (Janick J. ed.) ASHA Press, Alexandria, VA.

Hochmuth, G. D. Maynard, C. Vavrina, E. Hanlon, and E. Simonne. (2006). Plant Tissue Analysis and Interpretation for Vegetable Crops in Florida. University of Florida, Institute of Food and Agricultural Sciences (UF/IFAS). Available at:http://edis.ifas.ufl.edu.Ep081. Accessed: $18^{\text {th }}$ March, 2006

Jones, G. M., J. Hughes, A. Tregova, J.

Milne, A. Brian and H. Collin (2004). Biosynthesis of the Flavour Precursor of Onion and Garlic. Journal of Experimental Botany. 55(404): 19031918.

Ketter, C. A. and W. M. Randle. (1998). Pungency Assessment In Onions. In: Tested Studies for Laboratory Teaching, Proceedings of the $19^{\text {th }}$ Workshop of the Association of Biology Laboratory Education (ABLE). (Karcher, S. J. ed.) 19:177-196.

Ketiku, A.O., J.O.S. Kogbe and A.O. Omololu. (1985). Study on the Manurial Requirement of Nigerian Local Leafy Vegetables I. Effect of Poultry Manure on the Nutrient composition of Leaves of Amaranth and Nutrient Composition of Leaf and Bush Okra. Nigerian Journal of Agriculture. 19(20): 136144.

Osakwe, J. A. (1998). Effect of Wood Ash Application on the Growth and Development of Groundnuts (Arachis hypogeal). In: Sustainable Agricultural Investment in Nigeria. (Nwosu, A.C. and Mbanasor, J. A. ed).pp. 168-177.

Resemann, J. and Carle. (2003). Comparative Study on the Interaction Between Flavor Related Parameters of Different Onion Cultivars (Allium cepa L) and their Applicability to Forecasting Onion Oil Yield. Food Agriculture and Environment 1(3\&4): 104-111.

Watson, M. (2005). The Chemistry of Garlic: A Review of Analytical Methods. Garlic World. Available at: www.garlicworld.co.uk. Accessed February $20^{\text {th }}, 2006$.

Wong, Y.C.,C.T. Wong S.O. Onyiruka, and L.E. Akpanisi. (2001). University Organic Chemistry: The Fundamentals. African FEP Publishers Limited, Onithsha, Nigeria. pp - 